\title{
The Biosynthesis of Cyclic Carotenes
}

\author{
By R. J. H. WILLIAMS,* G. BRITTON* AND T. W. GOODWIN* \\ Department of Biochemistry and Agricultural Biochemistry, \\ University College of Wales, Aberystwyth
}

(Received 14 April 1967)

\begin{abstract}
1. The incorporation of $(3 R S)-\left[2-14 \mathrm{C},(4 R)-4-{ }^{3} \mathrm{H}_{1}\right]$ mevalonic acid into various cyclic carotenes in the fruit of the tomato mutant delta has been studied. The results confirm our previous view that the $\alpha$-ionone ring of $\alpha$-carotene does not arise by isomerization of a $\beta$-ionone residue, and show that the same is also true for the $\alpha$-ionone ring of $\delta$ - and $\epsilon$-carotene and $\alpha$-zeacarotene. 2. The incorporation of $(3 R S)$ - $\left[2-{ }^{14} \mathrm{C}, 2-{ }^{3} \mathrm{H}_{2}\right]$ mevalonic acid into $\alpha$ - and $\beta$-carotene in carrot roots has been studied. The results show that the $\beta$-ionone ring of $\beta$-carotene does not arise by isomerization of the $\alpha$-ionone residue of $\alpha$-carotene. 3. These experiments show that $\alpha$ - and $\beta$-ionone rings in cyclic carotenes are formed independently, probably by elimination of different protons from the same carbonium ion intermediates.
\end{abstract}

It has been suggested that cyclization to form $\alpha$ and $\beta$-ionone rings occurs at a late stage in the biosynthesis of the cyclic carotenes. Two possible sequences are generally considered, the first of which involves cyclization to form one type of ring, which then isomerizes to give the other common ring type (Scheme $1 a$ and $1 b$ ). The isomerization in Scheme $\mathbf{l}(b)$ is easily accomplished chemically (Karrer \& Jucker, 1947).

The second possibility is that the $\alpha$-and $\beta$-ionone rings are formed independently by loss of different protons to stabilize the carbonium ion formed as the primary cyclization product (Scheme 2).

The use of species of MVA $†$ labelled with ${ }^{14} \mathrm{C}$ and with ${ }^{3} \mathrm{H}$ in various positions has enabled a study to

* Present address: Department of Biochemistry, University of Liverpool.

† Abbreviation: MVA, mevalonic acid. be made of the mechanism of the cyclization, by following the retention or elimination of the hydrogen atoms involved.

\section{EXPERIMENTAL}

$(3 R S)-\left[2 \cdot{ }^{-14} \mathrm{C},(4 R)-4-{ }^{-3} \mathrm{H}_{1}\right] M V A$. This material (specific activity $0.825 \mu \mathrm{o}$ of ${ }^{14} \mathrm{C}$ and $6.12 \mu \mathrm{o}$ of ${ }^{3} \mathrm{H} / \mu$ mole) was kindly provided by Professor G. Popják and Professor J. W. Cornforth.

$(3 R S)-\left[2-14 \mathrm{C}, 2-{ }^{3} \mathrm{H}_{2}\right] M V A$. This material (specific activity $2.5 \mu \mathrm{C}$ of ${ }^{14} \mathrm{C}$ and $50 \mu \mathrm{O}$ of ${ }^{3} \mathrm{H} / \mu$ mole) was made by mixing [2.14C]mevalonic acid lactone $(0.1 \mathrm{mo}$; specific activity $5.03 \mathrm{mo} / \mathrm{m}$-mole) with $\left[2-{ }^{3} \mathrm{H}_{2}\right]$ mevalonic acid lactone $(2.0 \mathrm{mo}$; specific activity $102 \mathrm{mo} / \mathrm{m}-\mathrm{mole})$. Both [2-14C]and $\left[2 \cdot \mathrm{H}_{2}\right]$-mevalonic acid lactones were obtained from The Radiochemical Centre, Amersham, Bucks.

Plant materials. The tomato strain used was the delta mutant, seeds of which were kindly provided by $\operatorname{Dr} M$. L. (a)<smiles>CC=CC=C(C)CCC=C(C)C</smiles>

(b)<smiles>CC=CC=C(C)CCC=C(C)C</smiles><smiles>CC=CC1=C(C)CCCC1(C)C</smiles>

$\beta$-Ionone<smiles>CC=CC1C(C)=CCCC1(C)C</smiles><smiles>CC=CC1C(C)=CCCC1(C)C</smiles>

$\alpha$-Ionone<smiles>CC=CC1=C(C)CCCC1(C)C</smiles>

$\beta$-Ionone

Scheme 1. 


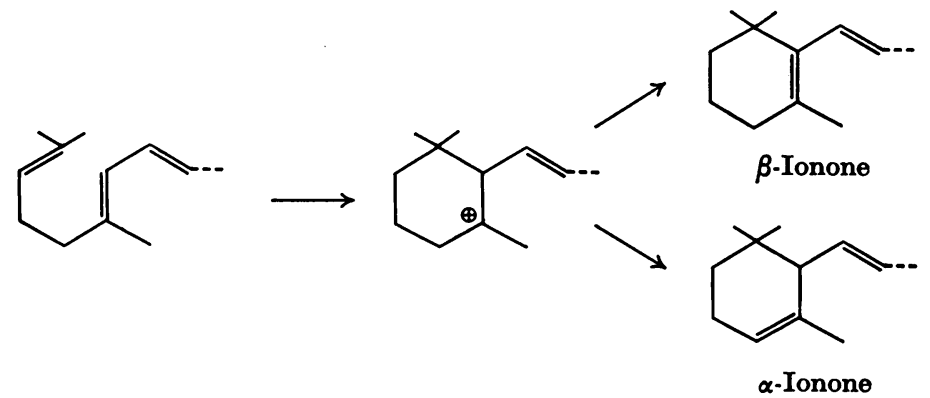

Scheme 2.<smiles>CC(=CC=CC=C(C)CCC1C(C)CCCC1C)CCC=C(C)CCC1=C(C)CCC=C1C</smiles>

(I)<smiles>CC1=C(/C=C/C(C)=C/C=C/C(C)=C/C=C/C=C(C)/C=C/C=C(C)/C=C/C2=C(C)CCCC2(C)C)C(C)(C)CCC1</smiles>

(II)<smiles>CC1=CCCC(C)(C)[C@]1([Tl])/C=C/C(C)=C/C=C/C(C)=C/C=C/C=C(C)/C=C/C=C(C)/C=C/C1=C(C)CCCC1(C)C</smiles>

(III)

Tomes, Purdue University, Lafayette, Ind., U.S.A. The seeds were germinated and grown in a greenhouse. Carrots were bought locally.

Incubations. Ripe tomato fruit were used, and slices taken from the central portions were immediately floated on a medium containing 0.1 M-tris- $\mathrm{HCl}$ (Sigma 7-9) buffer, pH 7·2-7.4, and the labelled MVA. Carrot root slices (1-2 mm. thick) were prepared and incubated in the same way.

Extraction, separation and purification of pigments. The methods used have been fully described previously (Williams, Britton, Charlton \& Goodwin, 1967; Goodwin \& Williams, 1965a).

Measurement of radioactivity. Samples were assayed for ${ }^{14} \mathrm{C}$ and ${ }^{3} \mathrm{H}$ in a Packard Tri-Carb liquid-scintillation spectrometer as previously described (Williams et al. 1967). Each sample was assayed three to five times on four separate occasions, from which the final average count and s.E.M. were calculated.

\section{RESULTS AND DISCUSSION}

Previous experiments (Goodwin \& Williams, 1966) have shown that $(3 R S)-\left[2-{ }^{14} \mathrm{C},(4 R)-4-{ }^{3} \mathrm{H}_{1}\right]-$
MVA is incorporated into phytoene (the $\mathbf{C}_{40}$ carotene precursor) in a number of organisms without loss of ${ }^{3} \mathrm{H}$, i.e. the ${ }^{3} \mathrm{H} /{ }^{14} \mathrm{C}$ atomic ratio in phytoene biosynthesized from $\left[2-{ }^{14} \mathrm{C},(4 R)-4-{ }^{-3} \mathrm{H}_{1}\right] \mathrm{MVA}$ is $8: 8$. Thus phytoene (I) formed from this substrate should have labelled hydrogen atoms at C-6 and C-6' (carotene numbering). $\beta$-Carotene (II), biosynthesized from the same substrate, in Phycomyces blakesleeanus and in carrot root slices had a ${ }^{3} \mathrm{H} /{ }^{14} \mathrm{C}$ atomic ratio $6: 8$ (Goodwin \& Williams, $1965 a$ ), showing that two labelled hydrogen atoms originally present in phytoene had been lost. This result was to be expected, since no hydrogen atom is present at C-6 of a carotene with a $\beta$-ionone ring.

If, as postulated by Anderson \& Porter (1962), $\alpha$-carotene is formed by isomerization of $\beta$-carotene, then $\alpha$-carotene should have the same ${ }^{3} \mathrm{H} /{ }^{14} \mathrm{C}$ atomic ratio as $\beta$-carotene, i.e. 6:8. The ${ }^{3} \mathrm{H} /{ }^{14} \mathrm{C}$ atomic ratio observed for $\alpha$-carotene was, however, $7: 8$ (Goodwin \& Williams, 1965b), showing that only one labelled hydrogen atom had been lost, pre- 

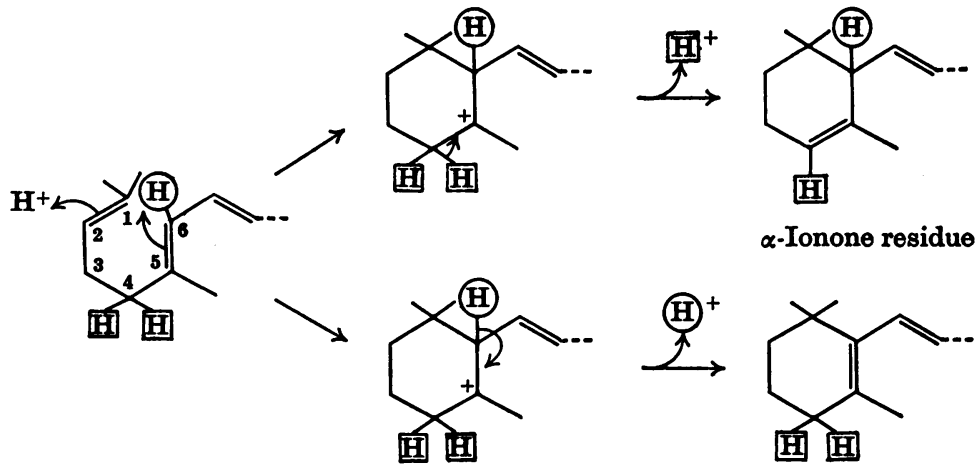

$\alpha$-Ionone residue

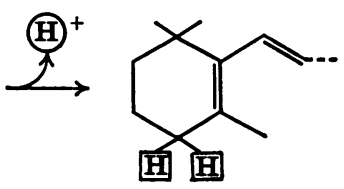

$\beta$-Ionone residue

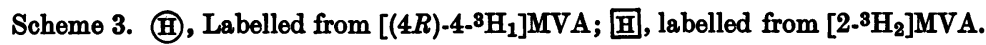

sumably in the formation of the $\beta$-ionone ring, and that the labelled hydrogen atom was retained at C-6' of $\alpha$-carotene (III). The $\alpha$-ionone ring of $\alpha$-carotene therefore does not arise by isomerization of a $\beta$-ionone ring, but is formed independently.

A mechanism was proposed (Scheme 3) in which cyclization of an acyclic precursor is initiated by proton attack at C-2 (carotene numbering), and the resulting intermediate carbonium ion is neutralized by loss of a proton, either from C-6 in the formation of a $\beta$-ionone residue or from $\mathrm{C}-4$ in the formation of the $\alpha$-ionone residue. According to this mechanism $\beta$-carotene, with two $\beta$-ionone residues, when synthesized from $(3 R S)-\left[2-{ }^{14} \mathrm{C},(4 R)-4-{ }^{3} \mathrm{H}_{1}\right] \mathrm{MVA}$, should lose two labelled hydrogen atoms originally present in phytoene or the acyclic precursor, whereas $\alpha$-carotene, with on $\theta \alpha$-ionone and one $\beta$-ionone residue, should lose only one labelled hydrogen atom. The observed ${ }^{3} \mathrm{H} /{ }^{14} \mathrm{C}$ atomic ratios are in accordance with this.

Part of the present investigation extends these observations to a study of the formation of $\gamma$ carotene (IV), $\delta$-carotene (V), $\epsilon$-carotene (VI) and $\alpha$-zeacarotene (VII), as well as $\alpha$-and $\beta$-carotene, in the fruit of a tomato mutant delta, which synthesizes all these cyclic pigments, in contrast with normal tomatoes, which produce mainly the acyclic lycopene (VIII) and only small amounts of $\alpha$ - and $\beta$-carotene (Williams et al. 1967).

The results of an experiment on the incorporation of $\left[2-{ }^{14} \mathrm{C},(4 R)-4-{ }^{3} \mathrm{H}_{1}\right] \mathrm{MVA}$ into the various carotenoid polyenes in delta tomatoes are outlined in Table 1.

In previous studies it had been assumed that no loss of hydrogen originating from C-4 of MVA would occur in the conversion of phytoene into the unsaturated precursor, either neurosporene or lycopene, of the cyclic carotenes. There was no reason to expect any loss, but in the present work this assumption has been shown to be valid. Thus, since the observed ${ }^{3} \mathrm{H} /{ }^{14} \mathrm{C}$ ratio in phytoene represents a ${ }^{3} \mathrm{H} /{ }^{14} \mathrm{C}$ atomic ratio $8: 8$, this atomic ratio is also obtained for acyclic carotenes, such as $\zeta$-carotene and lycopene, irrespective of their level of dehydrogenation.

The ${ }^{3} \mathrm{H} /{ }^{14} \mathrm{C}$ atomic ratios $6: 8$ and $7: 8$ for $\beta$ carotene and $\alpha$-carotene respectively confirm our previous results with carrot root slices and Phycomyces blakesleeanus (Goodwin \& Williams, 1965a,b).

The ${ }^{3} \mathrm{H} /{ }^{14} \mathrm{C}$ atomic ratios expected if Scheme 3 were operating were also observed for $\boldsymbol{\gamma}$-carotene (7:8) (one $\beta$-ionone residue and one open end; IV) and $\delta$-carotene $(8: 8)$ (one $\alpha$-ionone residue and one open end; V). Two compounds the identity of which was not rigorously established (Williams et al. 1967), $\epsilon$-carotene and $\alpha$-zeacarotene, gave results consistent with these structures, i.e. $\epsilon$-carotene $(8: 8)$ (two $\alpha$-ionone residues; VI) and $\alpha$-zeacarotene (8:8) (one $\alpha$-ionone residue, one open end; VII). In every case in which a $\beta$-ionone ring was formed, the hydrogen atom from C-6 (carotene numbering) was lost, whereas this hydrogen atom was always retained in the acyclic carotenes and in the formation of the $\alpha$-ionone residue. It is clear from these results that $\alpha$-carotene is not formed from $\beta$-carotene, nor $\delta$-carotene from $\gamma$-carotene, nor $\alpha$ zeacarotene from $\beta$-zeacarotene. If any of these conversions were taking place, the $\alpha$-series would have the same ${ }^{3} \mathrm{H} /{ }^{14} \mathrm{C}$ atomic ratios as the $\beta$-series.

In the pigments studied therefore no conversion of a $\beta$-ionone residue into an $\alpha$-ionone residue or an open chain had occurred. The possibility still remained, however, that the $\beta$-ionone residue might arise by isomerization of an $\alpha$-ionone ring (Scheme 4). The isomerization of $\alpha$-carotene to $\beta$-carotene, for example, is easily carried out in vitro (Karrer \& Jucker, 1947). $\beta$-Carotene biosynthesized from $\left[2-{ }^{14} \mathrm{C},(4 R)-4-{ }^{3} \mathrm{H}_{1}\right] \mathrm{MVA}$ would still have a ${ }^{3} \mathrm{H} /{ }^{14} \mathrm{C}$ 
<smiles>CC(C)=CCCC(C)=CC=CC(C)=CC=CC(C)=CC=CC=C(C)C=CC=C(C)C=CC1=C(C)CCCC1(C)C</smiles>

(IV)<smiles>CC(C)=CCCC(C)=CC=CC(C)=CC=CC(C)=CC=CC=C(C)C=CC=C(C)C=CC1C(C)=CCCC1(C)C</smiles>

(V)<smiles>CC1=CCCC(C)(C)C1/C=C/C(C)=C/C=C/C(C)=C/C=C/C=C(C)/C=C/C=C(C)/C=C/C1C(C)=CCCC1(C)C</smiles>

(VI)<smiles>CC(C)=CCCC(C)=CCCC(C)=CC=CC(C)=CC=CC=C(C)C=CC=C(C)C=CC1C(C)=CCCC1(C)C</smiles>

(VII)<smiles>CC(C)=CC=CC(C)=CC=CC=C(C)C=CC=C(C)C=CC=C(C)CCC=C(C)C</smiles>

(VIII)

Table 1. Incorporation of $(3 R S) \cdot\left[2 \cdot{ }^{14} \mathrm{C},(4 R)-4-{ }^{3} \mathrm{H}_{1}\right] M V A$ into carotenoid polyenes in delta tomatoes

Slices (70g. wet wt.) were incubated for $49 \mathrm{hr}$. at $23-25^{\circ}$ with $(3 R S)-\left[2-14 \mathrm{C},(4 R)-4-{ }^{3} \mathrm{H}_{1}\right] \mathrm{MVA}$ containing $0.80 \mu \mathrm{O}$ of ${ }^{14} \mathrm{C}$ and $8 \cdot 12 \mu \mathrm{C}$ of ${ }^{3} \mathrm{H}$. Incorporation into unsaponifiable matter was $43 \cdot 1 \%$ of the active isomer. ${ }^{3} \mathrm{H} /{ }^{14} \mathrm{C}$ atomic ratios are calculated assuming the ratio for phytoene to be 8:8, and are given as means ( \pm s.E.M. in parentheses).

\begin{tabular}{|c|c|c|c|c|}
\hline \multirow[b]{2}{*}{ Polyene } & \multicolumn{2}{|c|}{$\begin{array}{c}\text { Radioactivity } \\
\text { (disintegrations/min.) }\end{array}$} & \multirow{2}{*}{$\begin{array}{c}\text { Mean }{ }^{3} \mathrm{H} /{ }^{14} \mathrm{C} \\
\text { radioactivity } \\
\text { ratio }\end{array}$} & \multirow{2}{*}{$\begin{array}{c}\text { Mean }{ }^{3} \mathrm{H} /{ }^{14} \mathrm{C} \\
\text { atomic ratio }\end{array}$} \\
\hline & ${ }^{3} \mathrm{H}$ & ${ }^{14} \mathrm{C}$ & & \\
\hline$\left[2-{ }^{14} \mathrm{C},(4 R)-4-{ }^{3} \mathrm{H}_{1}\right] \mathrm{MVA}$ & 23910 & 4450 & $5 \cdot 37$ & $1: 1$ \\
\hline Squalene & 328800 & 65500 & $5 \cdot 02$ & $6: 6$ \\
\hline Phytoene & 8470 & 1700 & 4.98 & $8: 8$ \\
\hline$\zeta$-Carotene & 350 & 70 & 4.95 & $8.05( \pm 0.31): 8$ \\
\hline$\alpha$-Zeacarotene & 111 & 20 & $5 \cdot 07$ & $8.19( \pm 0.78): 8$ \\
\hline$\delta$-Carotene & 35600 & 7620 & $4 \cdot 70$ & $7.59( \pm 0.04): 8$ \\
\hline$\epsilon$-Carotene & $\mathbf{5 2 9}$ & 105 & $5 \cdot 04$ & $8.04( \pm 0.33): 8$ \\
\hline$\gamma$-Carotene & 5130 & 1170 & $4 \cdot 38$ & $7.05( \pm 0.07): 8$ \\
\hline$\alpha$-Carotene & 1770 & 406 & $4 \cdot 36$ & $6.95( \pm 0.11): 8$ \\
\hline$\beta$-Carotene & 4470 & 1205 & $3 \cdot 71$ & $5.95( \pm 0.33): 8$ \\
\hline Lycopene & 4640 & 960 & $4 \cdot 84$ & $7.76( \pm 0.12) ; 8$ \\
\hline
\end{tabular}


atomic ratio 6:8 if it were formed in this way. However, Scheme 3 shows that a hydrogen atom is lost from C-4 (carotene numbering) in the formation of the $\alpha$-ionone ring. The two hydrogen atoms at this position would be labelled in the acyclic precursor biosynthesized from $\left[2-{ }^{14} \mathrm{C}, 2-{ }^{3} \mathrm{H}_{2}\right] \mathrm{MVA}$, and the incorporation of this substrate into $\alpha$ - and $\beta$-carotene in carrot root slices was therefore studied. The results are shown in Table 2.

If $\beta$-carotene is formed as indicated in Scheme 3,

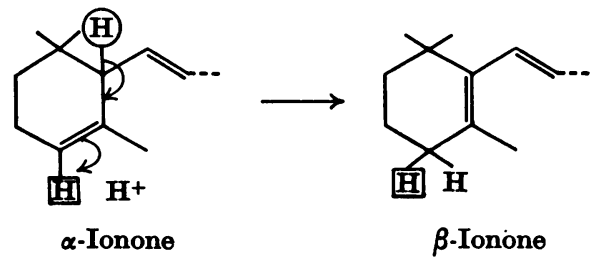

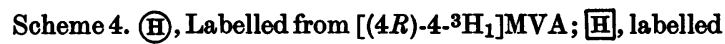
from $\left[2 \cdot{ }^{3} \mathrm{H}_{2}\right]$ MVA. it should have a ${ }^{3} \mathrm{H} /{ }^{14} \mathrm{C}$ atomic ratio $12: 8$ (IX) and the ratio for $\alpha$-carotene should be 11:8 (X). If $\beta$-carotene is formed from $\alpha$-carotene, the ratios should be the same, 11:8, or, if in each case the $\beta$-ionone ring were formed by isomerization of an $\alpha$-ionone residue (i.e. via $\epsilon$-carotene), 10:8. The observed ${ }^{3} \mathrm{H} /{ }^{14} \mathrm{C}$ atomic ratios are $12: 8$ for $\beta$ carotene and 11:8 for $\alpha$-carotene, showing that the $\beta$-ionone rings in $\alpha$ - and $\beta$-carotene are not formed by isomerization of $\alpha$-ionone residues, and also that $\beta$-carotene does not arise via $\alpha$-carotene. The same ratios, 12:8 and 11:8 respectively, have been obtained for $\beta$ - and $\alpha$-carotene produced by bean leaves in the presence of $\left[2-14 \mathrm{C}, 2-{ }^{3} \mathrm{H}_{2}\right] \mathrm{MVA}$ (Charlton, 1966). These results again suggest the mechanism shown in Scheme 3, according to which the carbonium ion intermediate may lose either of two protons to form $\alpha$-and $\beta$-ionone derivatives.

A more detailed consideration of the mechanism of cyclization outlined in Scheme 3 reveals a number of further points (Scheme 5). Cyclization can occur in either of two ways: the terminal double bond can

Table 2. Incorporation of $(3 R S)-\left[2-{ }^{14} \mathrm{C}, 2-{ }^{3} \mathrm{H}_{2}\right] M V A$ into squalene, phytoene, $\beta$-carotene and $\alpha$-carotene by slices of carrot root

Slices (18.2g. wet wt.) were incubated for $70 \mathrm{hr}$. at $21-23^{\circ}$ with $(3 R S)$-[2-14 $\left.\mathrm{C}, 2-{ }^{3} \mathrm{H}_{2}\right] \mathrm{MVA}$ containing $5 \mu \mathrm{C}$ of ${ }^{14} \mathrm{C}$ and $100 \mu \mathrm{C}$ of ${ }^{3} \mathrm{H}$. ${ }^{3} \mathrm{H} /{ }^{14} \mathrm{C}$ atomic ratios are calculated assuming the ratio for squalene to be $12: 6$, and are given as means ( \pm S.E.M. in parentheses).

\begin{tabular}{|c|c|c|c|c|}
\hline \multirow[b]{2}{*}{ Polyene } & \multicolumn{2}{|c|}{$\begin{array}{c}\text { Radioactivity } \\
\text { (disintegrations/min.) }\end{array}$} & \multirow{2}{*}{$\begin{array}{c}\text { Mean }{ }^{3} \mathrm{H} /{ }^{14} \mathrm{C} \\
\text { radioactivity } \\
\text { ratio }\end{array}$} & \multirow{2}{*}{$\begin{array}{l}\text { Mean }{ }^{8} \mathrm{H} /{ }^{14} \mathrm{C} \\
\text { atomic ratio }\end{array}$} \\
\hline & ${ }^{3} \mathbf{H}$ & ${ }^{14} \mathrm{C}$ & & \\
\hline ue & 85248 & 5416 & $15 \cdot 74$ & $12: 6$ \\
\hline & 87028 & 5568 & $15 \cdot 63$ & $15.90( \pm 0.30): 8$ \\
\hline$\beta$-Carotene & 55175 & 4575 & $12 \cdot 06$ & $12.25( \pm 0.25): 8$ \\
\hline$\alpha$-Carotene & 23074 & 2075 & $11 \cdot 12$ & $11 \cdot 39( \pm 0.10): 8$ \\
\hline
\end{tabular}

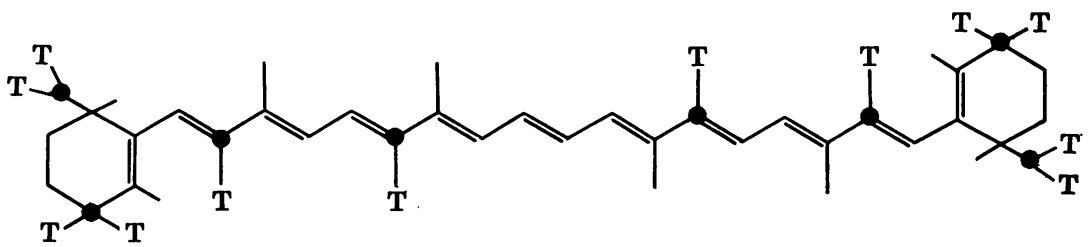

(IX)

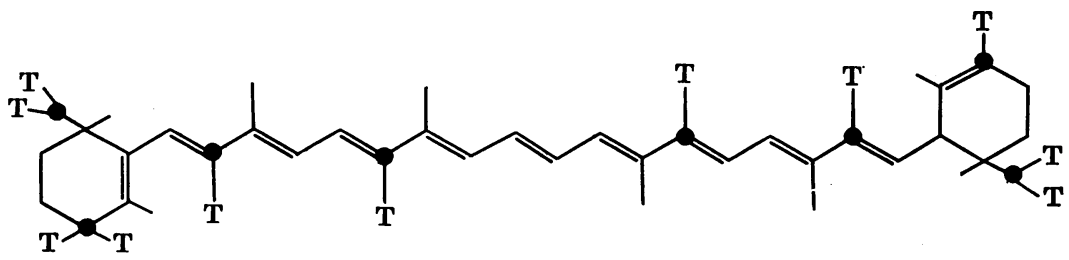

(X)

๑, Label from [2-14C]MVA; T, label from $\left[2 \cdot{ }^{3} \mathrm{H}_{2}\right] \mathrm{MVA}$. 
(a)

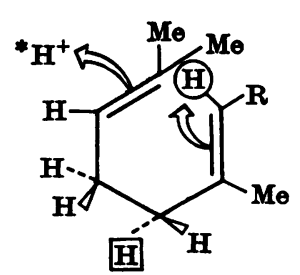

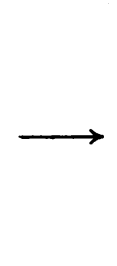

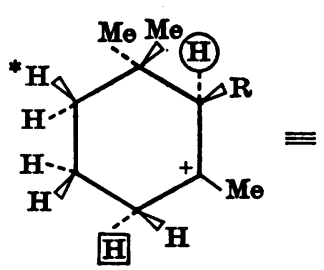

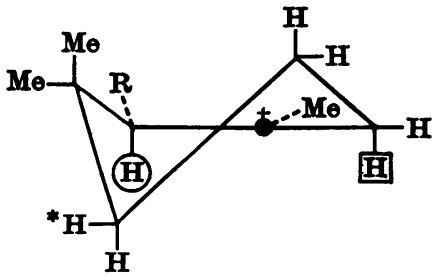

(A)

(b)

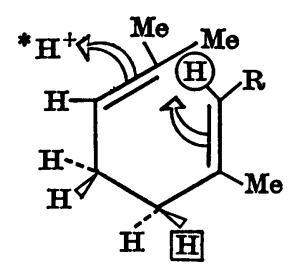

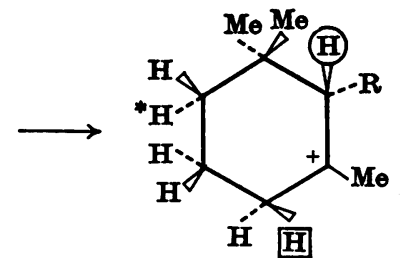

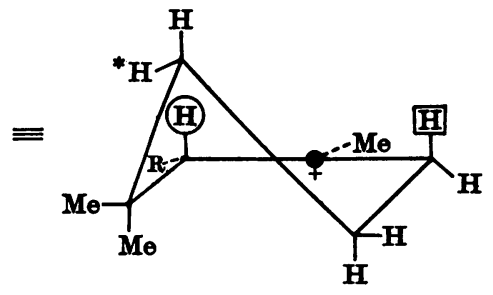

(B)

(c)

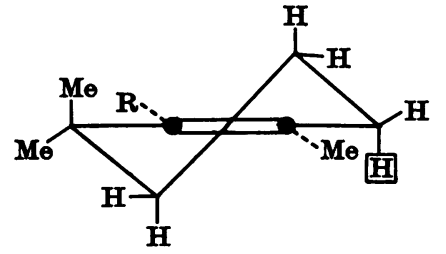

$\beta$-Carotene

III

(d)

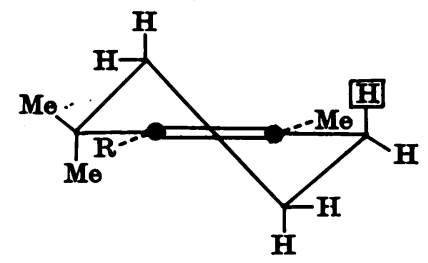

$\beta$-Carotene<smiles>CC1[C+]C1</smiles>

$\stackrel{\text { HI }}{+}$

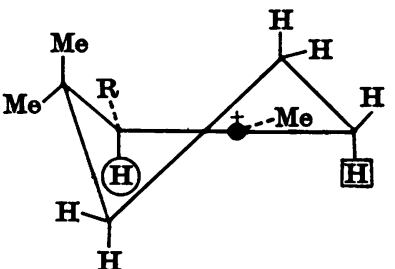

(A)<smiles>C[CH+][C@@H]1CCC1C</smiles>

$\alpha$-Carotene $(C)$<smiles>[R]C(C)(C)C1([R])CCCC(C)(C)C1</smiles>

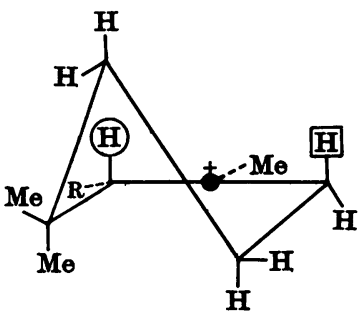

(B)

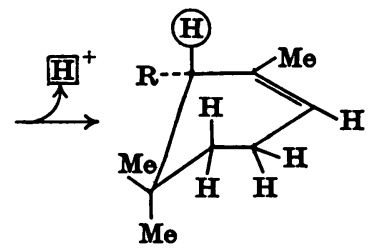

$\alpha$-Carotene (D)

Scheme 5.

be positioned either above or below the C-5 double bond (carotene numbering) when the protoninitiated cyclization takes place. Thus cyclization by proton attack from above the terminal double bond, which in turn is positioned above the C-5 double bond, would give the intermediate carbonium ion $(A)$ (Scheme 5a). On the other hand, cyclization by proton attack from below the terminal double bond, which is positioned below the C-5 double bond, would give carbonium ion $(B)$ (Scheme $5 b)$. These carbonium ions, in fact, differ only in their configuration about the C-6 carbon atom, and would be optical isomers.
The hydrogen atoms at C-4 and C-6 in each of these intermediates are in the axial position, stereoelectronically favourable for elimination. Elimination of the hydrogen atom from C-6 of either of these intermediates would give the same $\beta$ carotene, but $\alpha$-carotene molecules with a different configuration about C-6, i.e. optical isomers, would be formed by loss of the axial hydrogen atom from C-4 in the two intermediates (Scheme $5 c$ and $5 d$ ). Thus intermediate $(A)$ would give $\alpha$-carotene $(C)$ with the $S$-configuration about C-6 (Scheme $5 c$ ), whereas intermediate $B$ would give $\alpha$-carotene $(D)$ with the $R$-configuration about C-6 (Scheme $5 d$ ). 


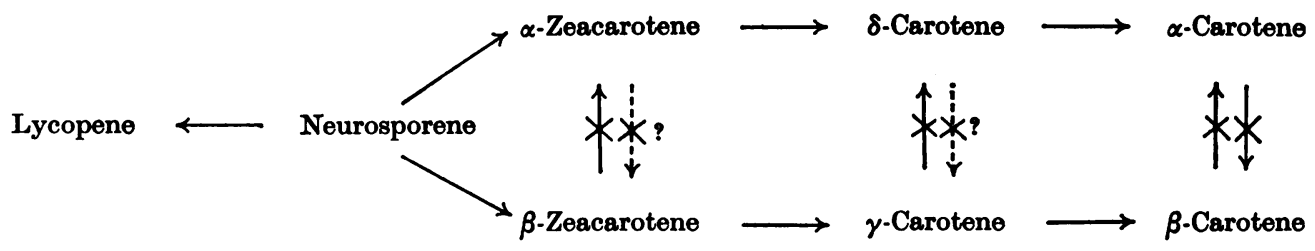

Scheme 6.

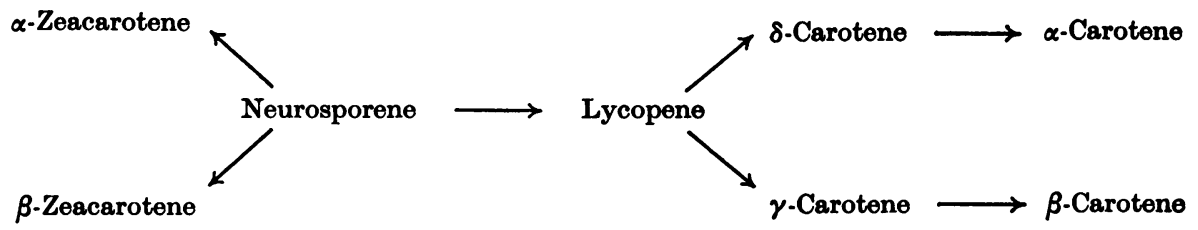

Scheme 7.

That only one of these possibilities in fact takes place is evident from the fact that $\alpha$-carotene isolated from a number of natural sources has a high optical activity (Karrer \& Jucker, 1950). The present work gives no information as to which of these possibilities is operative.

The present results show that, in the pigments and systems studied, no interconversion of $\alpha$ - and $\beta$ ionone residues of carotenes occurs, i.e. that these are synthesized independently. If neurosporene is taken to be the branch point for synthesis of cyclic carotenes (for the evidence see Goodwin, 1965), then the overall biosynthetic scheme shown in Scheme 6 for the formation of cyclic carotenes can be proposed. If lycopene and not neurosporene were the immediate precursor of the cyclic carotenes, then $\beta$-zeacarotene and $\alpha$-zeacarotene could be bypassed and appear as 'blind-alley' end products (Scheme 7).

The existence of these pigments in trace amounts in situations where either $\beta$-carotene or its derivatives or $\alpha$-carotene or its derivatives are being synthesized, as in maize (Simpson, Nakayama \& Chichester, 1964) and the delta tomatoes respectively, suggests that they are intermediates rather than end products.
This investigation was supported by a grant from the Science Research Council. R.J.H.W. was the holder of a Thomas and Elizabeth Williams Scholarship.

\section{REFERENCES}

Anderson, D. G. \& Porter, J. W. (1962). Arch. Biochem. Biophys. 97, 509.

Charlton, J. M. (1966). Ph.D. Thesis: University College of Wales, Aberystwyth.

Goodwin, T. W. (1965). In Biosynthetic Pathways in Higher Plants, p. 1. Ed. by Pridham, J. B. \& Swain, T. London: Academic Press (Inc.) Ltd.

Goodwin, T. W. \& Williams, R. J. H. (1965a). Biochem. J. 94, $5 \mathrm{c}$.

Goodwin, T. W. \& Williams, R. J. H. (1965b). Biochem. J. 97, 28c.

Goodwin, T. W. \& Williams, R. J. H. (1966). Proc. Roy. Soc. $B, 168,515$.

Karrer, P. \& Jucker, E. (1947). Helv. chim. Acta, 80, 266.

Karrer, P. \& Jucker, E. (1950). Carotenoids. Translated by Braude, E. A. Amsterdam: Elsevier Publishing Co.

Simpson, K. L., Nakayama, T. O. M. \& Chichester, C. 0. (1964). Abstr. 1st Meet. Fed. Europ. Biochem. Soc., London, p. 57.

Williams, R. J. H., Britton, G., Charlton, J. M. \& Goodwin, T.W.(1967). Biochem.J.104, 767. 